\title{
ANALYSIS OF IMPACT OF CAR, BOPO, NPF ON PROFITABILITY OF ISLAMIC BANKS (YEAR 2015-2017)
}

\author{
Wahyu Intan Kusumastuti ${ }^{1}$ and Azhar Alam ${ }^{2}$ \\ ${ }^{1}$ Faculty of Islamic Studies, Universitas Muhammadiyah \\ Surakarta \\ email: wahyuintan70@gmail.com \\ ${ }^{2}$ Faculty of Islamic Studies, Universitas Muhammadiyah \\ Surakarta \\ e-mail: aa123@ums.ac.id
}

\section{ABSTRACT}

Islamic banks have been known as the resistant banks to the global crisis that hit Indonesia a few years ago. The unique maintenance of Islamic bank performance leads to business continuity. Some Islamic bank performance can be measured by its profitability. There are some factors that affect the profitability Islamic bank and used in this study including CAR, BOPO, and NPF. While the purpose of this study is to determine the effect of CAR, BOPO and NPF on the profitability of Islamic commercial banks. The population of this research is the Islamic commercial bank whose financial statements have been published to the statistics of Islamic banks from 2015 -2017. This research used secondary data from OJK website. Data analysis in this paper conducted multiple linear regression analysis method. The results of this study indicate that the BOPO variable has a significant effect on ROA. On the other hand CAR and NPF variables have no significant effect on ROA.

Keywords: Impact, BOPO, NPF, Profitability, Islamic Commerical Banks 


\section{INTRODUCTION}

According to Banking Act no. 10 Year 1998 bank can be defined as a bank is a business entity that collects funds from the public in the form of savings and distributes to the community in the form of credit and or other forms in order to improve the standard of living of many people. The banking industry in Indonesia is increasingly crowded with the establishment of Islamic commercial banks. The development of Islamic banks gives an indication that the preference of Indonesian society is increasingly leading to Islamic transactions, the condition shows that the community has started to realize the existence of Islamic banks as a means of managing financial funds that based on Islamic principles that really blessed by Allah.

The existence of Islamic banking in Indonesia is currently increasing since the existence of Law no. 21 of 2008 on Islamic Banking which provides a clearer operating platform for Islamic banks. It can be justified from the Islamic institutional development that has been increasing since the issuance of Law no. 7 of 1992 concerning Banking. The existence of Islamic banks is also driven by the high interest of the public to place their funds in Islamic banks because the products of Islamic banking funds have an appeal to depositors considering the profit-sharing ratio and product margins are still competitive compared to interest in conventional banks.

The development of Islamic banking institute shows that the amendment of Law no. 7 of 1992 became Law no. 10 in 1998 responded positively by the perpetrators of the banking industry. This can be seen from the rapid growth of Islamic banking that exceeds the development of conventional banking. The development of Islamic banking is evident from the number 
of Islamic Commercial Banks operating to 12, followed by 22 Islamic Business Units, and 162 BPRS. These data indicate that the banking industry in Indonesia has enormous potential to develop.

The tight competition between Islamic banks and conventional banks, requires that Islamic banks must always improve their performance well in order to compete in the national banking market in Indonesia and create a bank with the principles of Islamic healthy and efficient. Banking performance is very important, because the banking business is a trust business, the bank must be able to show its credibility so that more people will be transacting the bank, one of them is through the increase of profitability. Profitability can be regarded as one of the most appropriate indicators to measure the performance of a company.Because the company ability to generate profits can be a benchmark of the company's performance. The higher the profitability, the better the company financial performance.

The usual ratios used to measure and compare the performance of bank profitability are Return On Equity (ROE) and ReturnOn Asset (ROA) (Suhardjono 2005). Both can be used to measure the financial performance of the banking industry. However, the Return On Equity (ROE) only measures the return earned from the investment of the owner of the company) while the Return On Asset (ROA) is used to measure the effectiveness of the company in generating profit to utilize its total assets (Siamat 2007).

Bank Indonesia as the supervisor and supervisor of banking prioritizes the profitability of a bank as measured by assets with funds mostly from public savings funds. The greater the Return On Asset (ROA) of a bank, the greater the level of profitability achieved by the bank and the better the bank's position in terms of 
asset use (Dendawijaya 2009). Therefore, in this study Return On Assets (ROA) is used as a measure of banking performance. The reason for choosing Return On Assets (ROA) as a performance measure is because ROA is used to measure the ability of bank management in obtaining overall profit.

There are several factors that can affect bank profitability, namely internal factors and external factors. Internal factor of the bank can be measured by using the financial ratios, because in analyzing financial statements will be easy if calculate the financial ratios of a company. Ratios affecting ROA are CAR, BOPO, NPF. While external factors are factors beyond the control of banks, these factors include exchange rate fluctuations, monetary policy, technological developments and competition among bank developers.

BOPO (cost-to-income ratio) which is a comparison between operational costs and operating income. The bigger the BOPO, the smaller the bank's ROA, because the profit earned by the small bank. Some previous studies showed that BOPO had no significant effect on ROA. While other researchs showed that BOPO had significant effect on ROA. With this research gap this paper try to do further research. According to the results of some research showed Non PerfomingLoan (NPL) has a negative and significant impact on Return On Assets (ROA). While the results of some research showed NonPerfoming Loan (NPL) has a negative and not significant impact on Return On Assets (ROA). In contrast to these results, other research indicated Non Perfoming Financing (NPF) has a positive and significant impact on Return On Assets (ROA). This research will examine the factors affecting ROA in Islamic bank in Indonesia such as CAR, BOPO, and NPF. 


\section{LITERATURE REVIEW}

\section{Definition of Banks}

According to Law No. 10/1998 on banking act, the Bank is defined as a business entity that receive from society in the form of savings and distributes it to the community in the form of credit and / or other forms in order to improve the standard of living of the people (Kasmir 2005). The Bank aims to support the implementation of national development and increase equity of development and drive economic growth and encourage national stability by improving the living standards of the people. In Indonesia Bank type consists of Commercial Banks and Rural Banks (Nadratuzzaman 2013) .

Based on the above definition, it can be seen that the main activity of the bank is to collect funds from the public in the form of savings that become the source of bank funds, then channeled in the form of credit, which should not only be driven by the motive to gain the maximum profit for owners but also aims for increasing standard living of people.

\section{Definition of Islamic Bank}

In general, Islamic bank is a financial institution whose main business is to provide credit and other services in the payment transaction and money circulation operating in accordance with the principles of Islamic. Islamic bank is a Bank that conducting its business activities based on Islamic principles which in its activities provide services in the payment trasanction.

The rule of Islamic bank agreement based on Islamic law between banks and other parties for the storage of funds or financing of business activities, or other activities stated in accordance with Islamic, among others, financing based on 
principles for (mudharabah), financing based on the principle of capital (musyarakah), the principle of sale and purchase of goods with profit (murabaha), or financing of capital goods based on the principle of pure lease without choice (ijarah), or with the option of transferring ownership of leased goods from the bank by another party (ijarahwa iqtina). So it can be concluded that the main difference between Islamic banking and conventional banking is the prohibition of interest (riba) for Islamic banking. Muhammad (2005) stated that the fundamental thing that distinguishes between non-Islamic financial institutions and Islamic is the return and profit sharing provided by customers to financial institutions and / or provided by financial institutions to customers.

The financing portfolio at commercial banks occupies the largest portion, generally around $50 \%-60 \%$ of total assets. From the financing issued or channeled banks are expected to get results. The yield on financing is the highest rate of income for the bank (Muhammad 2005). Thus, the source of revenue for Islamic banks can be obtained from profit sharing on mudaraba contract and musharaka contract, advantages on contract of sale - buy (al bai '), rents on ijarah and ijarah wa iqtina contracts, fee and administrative fees for other services.

\section{Islamic Financial Statement}

There are seven types of Islamic financial statements as explained by Suwiknyo (2010). First, balance Sheet, this is a report showing the financial position of the bank on a certain date, the intended financial position is the position of the assets (assets) and liabilities of a bank. Second, income statement describing the performance and business activities of Islamic banks in 
a certain period covering income and expenses incurred in the bank's main operations and other operations. Third, cashflow report that addresses all aspects related to the activities of the bank, either directly or indirectly affecting cash. The cash flow statement should be prepared based on the cash concept during the reporting period. Fourth equity change report that show changes in the bank's equity reflecting an increase or decrease in net assets or wealth during the reporting period. Fifth, report on the source of zakat funds derived from the external and internal entities of Islamic, the policy of disbursement of zakat to each asnaf. And the proportion of funds disbursed for each recipient of zakat is classified on the parties concerned. Sixth, source and use report of the virtue fund over a certain period of time, as well as a balance of demonstrated benevolent funds and virtues that have not been distributed on a specific date. Last, Notes to the financial statements include the information required to be disclosed in the PSAK and other disclosures necessary to produce reasonable presentation of financial statements

\section{Financial Ratio Analysis}

The ratio of finance is a study that looks at the comparisons of the amounts contained in the financial statements by using formulas that are considered representative for application. Ratio analysis is basically not only useful for internal corporate interests but also outside parties. Financial ratios can be classified into six types. First, liquidity ratio that is used to measure the company's ability to meet its short-term liabilities. Some liquidity ratios are often used in assessing the performance of a bank that is Cash Ratio, ReserveRequirement, Loan to Deposit Ratio, Loan to Assets Ratio, Ratio of net call liabilities. Second, solvency 
ratio (Leverage) that measure the extent to which the company is financed from debt. Some ratios are Capital Adequacy Ratio (CAR), Debt to Equity Ratio, Long Term Debt to Assets Ratio. Third, activity ratio, the ratio used to measure how effectively a company uses its resources. Fourth, profitability ratio to measure the effectiveness of management seen from the profits generated on sales and investment companies. Analysis of rentability ratios of a bank in this chapter include Return on Assets, Return on Equity, Net Profit Margin, Operational Ratio. Fifth, growth ratio to measure a company's ability to maintain its economic position in economic and industrial growth. Sixth, assessment ratio to measure management's ability to create market values that go beyond investment cost. The valuation ratio is the most complete measure of company performance, as it reflects the risk ratio (the first two ratios) and the returns ratio (the next three ratios). The ratio of valuation is very important because the ratio is directly related to the purpose of maximizing the value of the company and the wealth of the shareholders.

\section{Profitability}

Profitability is the result of the policy taken by management. Profitability ratioaims to measure how much the level of profits shows the better management in managing the company. The profitability of a company can be assessed in various ways depending on the profits and assets or capital to be compared with each other. Firms with high and stable profitability tend to be free from the practice of income smoothing because managers feel confident about their performance as measured by profits generated by companies, while firms with low profitability tend to open up the possibility of income smoothing because if the 
company has a level profitability is low then the performance of managers will be questioned by the owner of the company and the existence of the eyes of society will be doubted, this will also impact on investment decisions by investors. This study carry out Return On Assets (ROA) as the indicator used to measure profitability.

It should be noted here that in determining the soundness of a bank, Bank Indonesia is more concerned with the valuation of Return On Asset and does not include the Return On Equity element. This is because Bank Indonesia, as the supervisor and supervisor of the banking system, prioritizes the profitability of a bank as measured by assets with funds mostly from public savings funds (Dendawijaya 2009).

\section{Return On Asset (ROA)}

Return on Assets (ROA) is one of the ratios used to measure the bank's management capability in gaining overall profit. Return on Assets (ROA) is the ratio used to measure the ability of banks to earn an overall profit. The greater the Return On Assets (ROA), the greater the level of profit achieved by the bank and show the company's better performance.Return On Asset (ROA) is chosen as an indicator of financial performance of banking because Return On Asset (ROA) is used to measure the effectiveness of companies in generating profits by utilizing assets owned.

Return On Assets (ROA) is the ratio between profit before tax to average total assets. The greater the ROA, the greater the level of profit the bank . Based on the provisions of Bank Indonesia, ROA is formulated as follows:

$\mathrm{ROA}=($ Profit Before Tax $) /($ Average Total Assets $) \times 100 \%$ 


\section{Capital Adequency Ratio (CAR)}

Capital Adequency Ratio (CAR) is the ratio of capital ability to show how far bank assets have risks. The risk is also derived from the capital itself, where the bank obtained the capital from sources outside the bank. Under the terms of Bank Indonesia, the value of the Capital Adequency Ratio has a minimum value of eight percent ( $8 \%$ ). Therefore, bank management should increase the value of the Capital Adequency Ratio (CAR). When a capital is sufficient, then the bank can easily expand the business (business) in order to improve bank profitability. To obtain high profitability, many banks must be able to make Capital Adequency Ratio (CAR) ratio more than eight percent (8\%).In other words, Capital Adequency Ratio is the ratio of bank performance to measure the capital adequacy of the bank to support the assets that contain or generate risk.

$$
\mathrm{CAR}=(\text { Bank Capital }) /(\text { Total RWA }) \times 100 \%
$$

\section{Operating Cost of Operating Income (BOPO)}

BOPO is the ratio between operating costs and operating income. Operational cost ratio is used to measure the level of efficiency and ability of banks in conducting operations. Same smaller this ratio means the more efficient operational costs are laid by the bank concerned so that the possibility of a banks in less problematic conditions. The smaller this ratio then the better bank performance. Thus, the operating efficiency of a bank proxied by BOPO ratio will affect the bank's performance. Mathematically, BOPO can be formulated as follows:

$\mathrm{BOPO}=($ Operating Cost $) /($ Operating Income $) \times 100 \%$ 


\section{Non Performing Loan (NPF)}

According to the Dictionary of Bank Indonesia, Non Performing Loans (NPLs) or Non Performing Financing (NPF) are non performing loans consisting of substandard, doubtful and loss classifications. The NPL term is for commercial banks, while NPF for Islamic banks. Loans in this case are credits granted to third parties and excludes credits to other banks. While nonperforming loans are credits with substandard quality, doubtful, and loss. So the higher this ratio, the worse the credit quality of the bank that causes the number of problem loans is greater then the possibility of a bank in the increasingly troubled condition. Nonperforming loans are credits with substandard quality, doubtful and loss (Almilia, 2005). Hasbi (2011) wrote this NPF ratio can be formulated as follows:

$$
\mathrm{NPF}=(\text { Financing }) /(\text { Total Financing }) \times 100 \%
$$

\section{The Effect of CAR on ROA}

Capital Adequacy Ratio (CAR) is also commonly referred to as the capital adequacy ratio, measuring the capital adequacy of banks to support risk-bearing assets. This capital adequacy ratio is an indicator of the bank's ability to cover its asset decline as a result of bank losses caused by risky assets So with the increase in capital itself, the bank's health associated with the capital ratio (CAR) is increasing and with large capital then the opportunity to earn corporate profits is also getting bigger. Because with large capital, bank management is very flexible in placing the funds into investment activities that benefit. So it can be concluded that the higher the CAR, the higher the ROA. This is in accordance with research Mahardian which shows that the increasing CAR 
effect on ROA is also increasing. The Bank Indonesia Regulation concerning Capital Adequacy Ratio (CAR) states that the minimum CAR must be met by $8 \%$ bank. So the bank should always keep the CAR ratio always above $8 \%$. However, the CAR which is too high means that there is idle fund. Thus, the bank's opportunity to earn profits will decrease, consequently will reduce the bank profitability. The high CAR can be caused by the addition of capital from the owner in the form of fresh money to anticipate the development of business scale in the form of credit expansion. However, in fact, the bank intermediary function is still not optimal yet, wherein third party funds in the form of public funds deposits by Banks are given Bank Indonesia Certificates in which the SBR SBI is 0, thus the ATMR of Bank is relatively small, so Capital Adequacy Ratio (CAR) big. As a result, idle funds will also be large, so the profitability of banks proxied with Return On Assets (ROA) will decrease further.

\section{The Effect of BOPO on ROA}

$\mathrm{BOPO}$ is the ratio of the ratio between Operational Cost and Operating Income, the lower the ratio of BOPO means the better performance of the bank's management, because it is more efficient in using the existing resources in the company BOPO ratio shows the efficiency of the bank in running its main business, especially credit, where the loan interest becomes the biggest income of the bank. Financing management is needed by the bank, considering the financing function as the largest contributor of income for Islamic banks. The level of health financing (NPF) influences the achievement of bank profit (Suhada, 2009). The smaller BOPO indicates the more efficient the bank in carrying out its activities. A healthy bank BOPO ratio of less than 1 otherwise 
bank less healthy BOPO ratio is more than 1 . The higher the cost of the bank's income means that its operational activities are increasingly inefficient, so its opinion jugasemakin small. In other words BOPO negatively related to bank profitability.

\section{The Effect of NPF on ROA}

Non Performing Financing (NPF) which is analogous to Non Performing Loan (NPL) reflects the size of credit risk faced by the bank, the smaller Non Performing Loan (NPL), the less the credit risk borne by the bank. Thus, if a bank has a high Non Performing Loan (NPL), indicating that the bank is not professional in credit management, as well as providing an indication that the level of risk on the lending in the bank is quite high in line with the high NPL faced by banks (Riyadi, 2006 ). Credit risk proxied by Non Performing Financing (NPF) has a negative effect on the bank's financial performance proxyed with Return On Assets (ROA). Thus, the greater Non Performing Financing (NPF), will result in a decrease in Return On Assets (ROA), which also means the financial performance of banks that decline because of the greater credit risk. Vice versa, if the Non Performing Financing (NPF) down, then the Return On Assets (ROA) will increase, so the financial performance of banks can be said the better.

\section{Previous Research}

Previous research is conducted by Wibowo et al. (2013) entitled "Analysis of Influence of Interest Rate, Inflation, CAR, BOPO, NPF on Profitability of Islamic Bank", using data collection technique by purposive sampling. The method used is F-Statistic Test and t-Statistic Test. The result of research 
indicates that BOPO has significant effect to ROA while CAR, NPF, Inflation and Interest Rate variables have no effect.

The previous research conducted by Silfani Permata Sari, A (2017) under the title "The Influence Analysis of Capital Adequacy Ratio, Net Operating Margin, Fanancing To Deposit Ratio, Non Performing Financing and Profit Sharing Financing on Islamic Commercial Banks in Indonesia. (Case Study of Islamic Commercial Banks in Indonesia). Using population data collection techniques only take from several banks. The result of research shows that CAR variables have positive effect on profitability (ROA) of syariah bank, NOM variable have positive effect to Islamic bank profitability (ROA), FDR variable have positive effect on Islamic bank profitability (ROA), variable of NPF negatively affect profitability (ROA) Islamich, and profitsharing sharing have a positive effect on the profitability (ROA) of Islamic banks.

Previous research conducted by Iskandar et al. (2016) under the title "The Influence of Risk-Based Bank Rating Components to Profitability of Islamic Commercial Banks In Indonesia (Period 2011-2014)", using data collection techniques by purposive sampling.Method used is multiple linear regression . The results showed that all variables used to measure the four aspects of bank soundness rating by risk-based bak rating method, ie NPF, FDR, GCG composite value, BOPO, and CAR simultaneously significantly influence the profitability of Islamic commercial banks

Prior research conducted by Sri Windarti Mokoagow (2015), entitled "Factors Affecting Profitability of Islamic Commercial Banks in Indonesia", using data collection techniques in this study population of all Islamic Commercial Banks in Indonesia 
in 2011-2013. The method used is descriptive statistics, classical assumption test, multiple regression analysis, and hypothesis test. The result of research shows that CAR variable has a significant positive effect on profitability (ROA) of Islamic Commercial Bank, KAP variable has a significant negative effect on profitability (ROA) of Islamic Commercial Bank, BOPO variable has significant negative effect to Islamic Bank profitability (ROA) insignificant to the profitability (ROA) of Islamic Commercial Banks, and Minimum Reserve Requirements (GWM) variable positively insignificant to profitability (ROA) of Islamic Commercial Bank

Previous research conducted by Yeyen Kumalasari (2016) entitled "Analysis of Factors Affecting Profitability at Islamic Commercial Bank in Indonesia Period 2010-2014", using data collection techniques secondary obtained from the publication of the semester financial reports of several Banks at Commercial Banks Islamic. The method used is multiple linear regression. The research results show that simultaneously CAR, LTA, market share of financing have positive and significant impact to profitability of Islamic Commercial Bank period 2010-2014. In partial CAR have negative and significant impact on profitability (ROA, LTA Variables, Market Share, Financing, and NIM have a positive and significant impact on profitability of Islamic Commercial Bank.

\section{METHODS}

\section{Object and Type of Research Data}

The object of this research is the Influence of CAR, BOPO, NPF on Profitability of Islamic Commercial Bank. The study in this study is the Islamic Commercial Bank. The study intends to analyze the effect of CAR, BOPO, NPF on Profitability of 
Islamic Commercial Bank. Type of research that researchers use in this research is statistical research with descriptive approach. Descriptive statistics in research is basically a process of transforming research data in tabulation form so easily understood and interpreted. The type of data used in this study is secondary data obtained indirectly from third parties through intermediaries and various sources available. In this study the source data taken from the statistics of Islamic banking taken from the website www.ojk.go.id and other supporting data.

\section{Data Analysis Model}

The analysis model uses multiple linear regression analysis tool that is increase the number of free variable previously only one into two or more independent variables. In this study, multiple linear regression analysis is used to prove the extent to which the influence of CAR, BOPO, NPF on profitability of Islamic Commercial Bank. The authors replicate the model from Edhi Satriyo Wibowo, et al, 2013, Influence Analysis of Interest Rates, Inflation, CAR, BOPO, NPF Against Profitability of Syariah Commercial Bank.Diponegoro Journal of Management Vol.2, No. 2. With the model of the following regression equation:

$$
\mathrm{Y}=\mathrm{a}+\mathrm{b} 1 \times 1+\mathrm{b} 2 \times 2+\mathrm{b} 3 \times 3+\mathrm{e}
$$

Information:

$\mathrm{Y}=$ dependent variable $(\mathrm{ROA})$

a $\quad=$ Constants

b1-b3 = independent coefficient of independent

$\mathrm{x} 1=\mathrm{CAR}$ (Capital Adequacy Ratio) Interest Rate

$\mathrm{x} 2=\mathrm{BOPO}$ (International Expenditure per OO Revenue) 


$$
\begin{array}{ll}
\mathrm{x} 3 & =\text { NPF (Non Performing Fund) } \\
\mathrm{e} & =\text { Standard Error }
\end{array}
$$

\section{Classic Assumption Test}

There are several classic assumption test in this study. First, normality test This normality test aims to test whether in the regression model the dependent variable and the independent variable both have a normal distribution or not. A good regression model is a normal or near normal distribution. Second, Multicolinearity Test. The problem of multicollinearity arises when there is a definite or definite relationship between one or more independent variables in the model. In the case of serious multicollinearity, the regression coefficient no longer shows the pure effect of the independent variable in the model. Third, Heteroskedacity test. occurs when variance is not constant or varies with the change of independent variables. The consequence of the existence of the heteroskedasitas is the OLS regression method will produce a biased estimator for the ut variation value and thus the variation of the regression coefficient. Fourth autocorrelation test to prevent autocorrelation because it occurs when the value of a past variable has an effect on the value of the present, or future variable. The consequence of the existence of Autocorrelation is the OLS regression method will result in an overestimation of the value of ut variation and hence produce an overestimate estimate for R2. Fifth, Test Specification linearity model. This test is used to test CLRM assumptions about model linearity, so it is often referred to as model linearity test. This study used Ramsey Raset test as general to test specification error. 


\section{RESULTS AND DISCUSSION}

\section{The Profitability Development of Islamic Commercial Banks}

Profitability is the result of the policy taken by management. The profit ratio to measure how much the profit rate shows the better the management in managing the company. Profitability of a company can be assessed in various ways depending on the profits and assets or capital to be compared with each other. From the data collected by Syariah Banks in Islamic banking statistics shows profitability in 2015 - 2017. Profitability data can be shown by the following graph:

\section{Graph 1}

\section{Profitability Development of Islamic Commercial Banks 2015-2017}

\section{ROA (\%)}

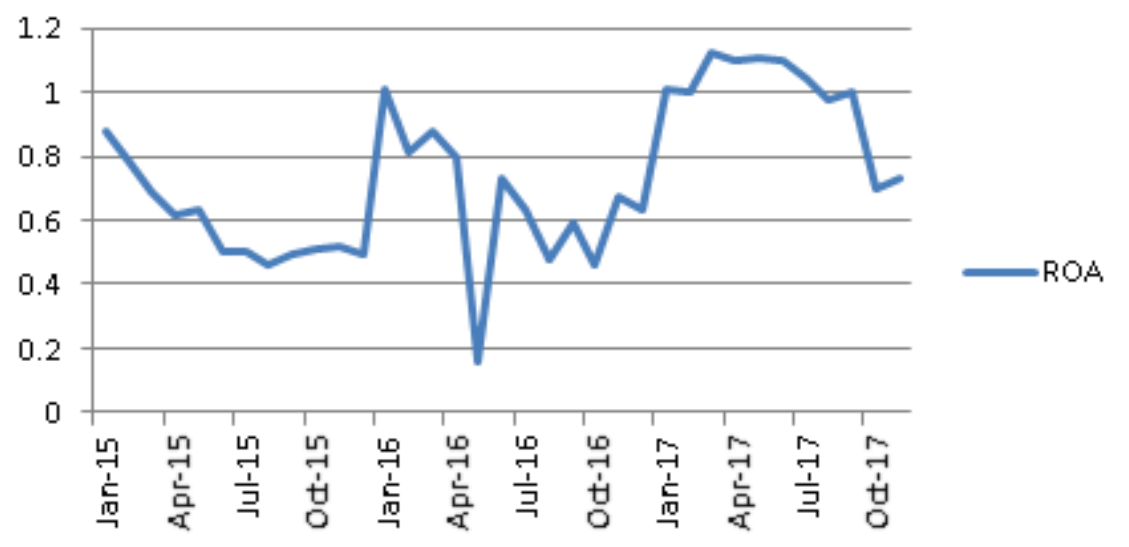

Source : Islamic Banking Statistic

Graph 1 above shows profitability of 2015-2017 had an initial increase in the beginning of 2016 at 1.01\%. In february 2016 it decreased at $0.81 \%$ until the end of 2016. In 2017 profitability increased again at $1.01 \%$. The increase and decrease 
of profitability development is not seen clearly in the graph above because the increase and decrease is not too significant.

\section{The Capital Adequacy Ratio (CAR) Development of Islamic Commercial Banks}

Capital Adequency Ratio is the ratio of capital ability to show how far bank assets have risks. The risk is also derived from the capital itself, where the bank obtained the capital from sources outside the bank. Under the terms of Bank Indonesia, the value of the Capital Adequency Ratio has a minimum value of eight percent. Therefore, bank management should increase the value of Capital Adequency Ratio.From the data collected at Islamic Commercial Banks in the statistics of Islamic banking show Capital AdequacyRatio (CAR) in 2015 - 2017.Data Capital AdequacyRatio (CAR) can be shown at graph the following graph

\section{Graph 2}

CAR Development of Islamic Commercial Banks 2015-2017

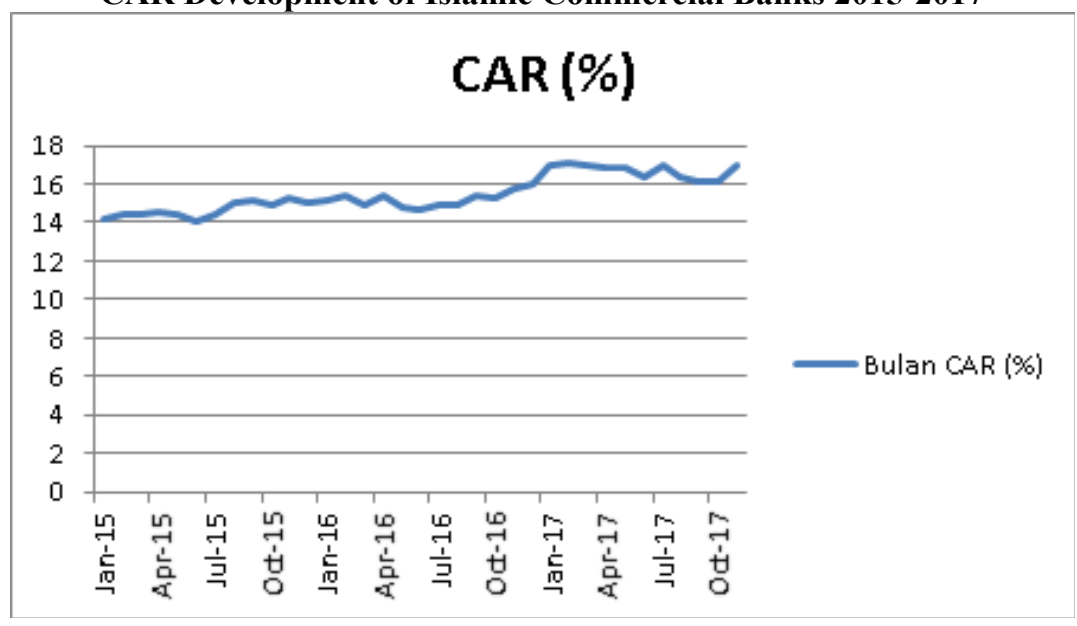

Source : Islamic Banking Statistic 
Based on graph 2 above, Capital AdequacyRatio (CAR) of 2015-2017 has increased in 2015 at $15.02 \%$ in 2016 has increased at $15.09 \%$. In 2017 again decreased at $17.00 \%$. The increase and decrease of Capital AdequacyRatio (CAR) development is not seen clearly in the graph above because the increase and decrease is not too significant.

\section{The Cost-to-Income Ratio (BOPO) Development of Islamic Commercial Banks}

Operating Cost to Operating Revenue Ratio is often called the operational efficiency ratio, this ratio is used to measure the ability of bank management in controlling operational costs to operating income. From collected data at Islamic banking statistics shows Operational Cost and Operating Income (BOPO) at 2015 - 2017. Operational Cost and Operating Income (BOPO) data can be shown at the following graph:

\section{Graph 3}

Cost-to-Income Ratio Development of Islamic Commercial Banks 20152017

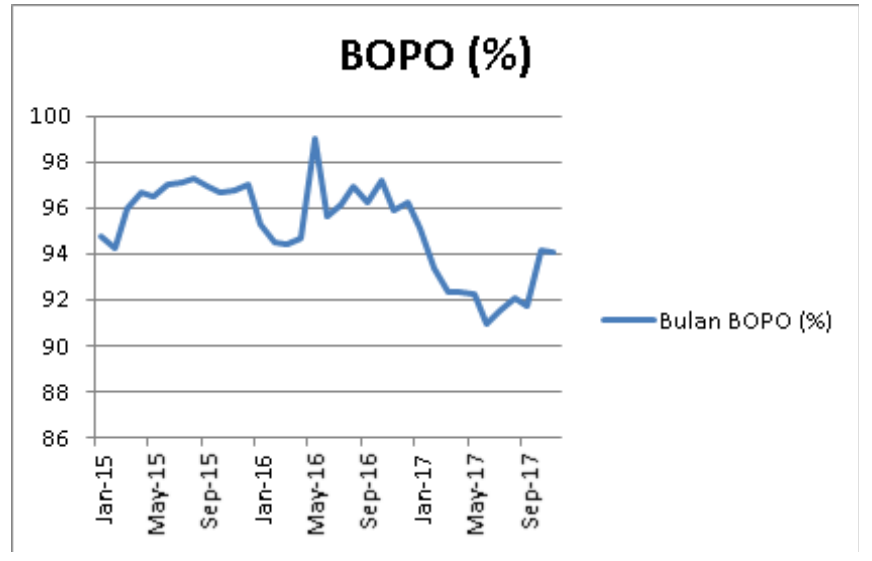

Source : Islamic Banking Statistic 
Based on graph 4.3 above, Cost-to-Income ratio (BOPO) of 2015-2017 increased in 2015 at level $97.01 \%$ and in 2016 decreased at level $96.23 \%$. In 2017 this ratio decreased to level $94.05 \%$. there were increase and decrease in the development of Cost-to-Income ratio (BOPO).

\section{The Non Performing Loan (NPF) Development of Islamic} Commercial Banks

Non Performing Financing is a comparison of financing provided to third parties and excludes financing of other banks. Non-performing financing is financing of substandard, doubtful, and loss. From the data collected at Syariah Banks in the statistics of syariah banking shows Non Performing Financing (NPF) in 2015 - 2017. Data Non Performing Financing (NPF) can be shown at the following graph:

\section{Graph 4}

\section{Performing Loan (NPF) Development of Islamic Commercial Banks}

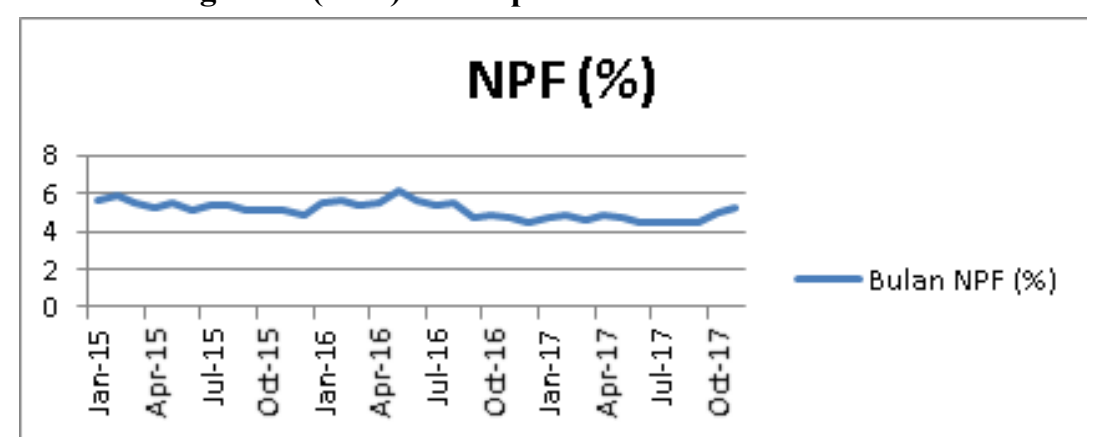

Source : Islamic Banking Statistic

Based on graph 4 above, Non Performing Financing (NPF) of 2015-2017 decreased in 2015 at $4.84 \%$ in 2016 decreased at $4.42 \%$, In 2017 increased at 5.27\% Increased and decreased 
development Non Performing Financing (NPF) is not seen clearly in the graph above because the increase and decrease is not too significant.

\section{Estimation Result}

In this research, as mentioned above, to know the effect of Capital Adequacy Ratio (CAR), Operational Cost and Operating Income (BOPO), Non Performing Financing (NPF) to Profitability of Islamic Commercial Banks during 2015-2017 period, ordinary regression analysis least square (OLS) with the econometric model as follows:

$$
\mathrm{ROA}=\mathrm{a}+\beta_{1} \mathrm{CAR}+\beta_{2} \mathrm{BOPO}+\beta_{3} \mathrm{NPF}+\mathrm{u}_{\mathrm{t}}
$$

Note:

$\mathrm{Y}=$ Dependent variable $(\mathrm{ROA})$

CAR $=$ Capital Adequacy Ratio

BOPO = Cost-to-Income Ratio

$\mathrm{NPF} \quad=$ Non Perfoming Financing

$\alpha \quad=$ Constants or intercept

$\beta_{1}, \beta_{2}, \beta_{3}=$ Regression coefficient of independent variables

$\mathrm{u} \quad=$ Component error (error term)

$t \quad=$ Time to $\mathrm{t}$ (for time series data, replace with $\mathrm{i}$ for cross section data)

The estimation results of the above econometric model along with the various complementary tests are summarized in Table 1 
Table 11

Estimation Result of Econometric Model

Profitability of Islamic Commercial Banking 2015-2017
$\widehat{R O A}_{t}=11.05352+0.006241 \mathrm{CAR}_{\mathrm{t}}-0.110703 \mathrm{BOPO}_{t}+$ $0.022916 \mathrm{NPF}_{t}$
$\frac{(0.8372)(0.0000) *(0.6701)}{\mathrm{R}^{2}=0.843111 ; \quad \mathrm{DW}-\text { Stat }=1.414835 ; \quad \text { F-Stat }=55.53079 \text { Sig. }}$
F-Stat $=0.000000$

Description: * Significant at $\alpha=0,01 ;{ }^{* *}$ Significant at $=0,05 ;{ }^{* * *}$ Significant at $\alpha=0,10$; The number in parentheses is the probability of the t-statistic value

Source : Islamic Banking Statistics (organized data)

\section{Classic Assumption Test}

\section{Multicolinearity Test (VIF Test)}

Multicollinearity test in this study using Variance Inflation Factor (VIF). A multicollinearity problem occurs when VIF ( $>$ 10). From Table 4.1, the value of VIF Capital Adequacy Ratio (CAR) of $2.770758(<10)$, VIF of Operating Income Operating Cost (BOPO) is $2.041429(<10)$, and VIF Non Perfoming Fund (NPF) value is $1.892556(<10)$. Conclusion there is no problem multicollinearity.

\section{Autocorrelation Test (Breusch Godfrey Test)}

Autocorrelation test in this study using Breusch Godfrey Test. H0 Breusch Godfrey Test: there is no problem of autocorrelation in the model. HA Breusch Godfrey Test: there is an autocorrelation problem in the model. H0 is accepted when the statistical significance of $\mathrm{x}^{\wedge} 2>\alpha$ and $\mathrm{H} 0$ is rejected when the significance of $\mathrm{x}^{\wedge} 2<\alpha$.From Table 4.1 in advance the value of 
Probability or $\operatorname{sig}\left(\mathrm{x}^{\wedge} 2\right)$ is $0.2352(>0.10)$, then $\mathrm{H} 0$ : there is no autocorrelation problem in the model.

\section{Linearity Test (Ramsey Reset Test)}

Linearity test in this research use Ramsey Reset Test. H0 Ramsey Reset test: linear model (exact model specification). HA Ramsey Reset test: not linear (model specifications are not exact). $\mathrm{H} 0$ is accepted when $\mathrm{F}$ arithmetic or $\operatorname{sig}(\mathrm{F})>\alpha$ and $\mathrm{H} 0$ are rejected if $\mathrm{F}$ arithmetic or sig $(\mathrm{F})<\alpha$. From Table 4.1 in advance seen the value of $\operatorname{Sig}(F)=0.0127(<0.05)$ then $\mathrm{H} 0$ rejected, means that the model used is a model that is not linear.

\section{Normality (Jarque Bera Test)}

Normality test in this study using Jarque Bera Test. H0 test Jarque Bera: normal ut distribution. HA Jarque Bera test: ut distribution is not normal. $\mathrm{H} 0$ is accepted when the statistical significance of $\mathrm{JB}>\alpha$ and $\mathrm{H} 0$ is rejected if statistical significance JB $<\alpha$.From Table 4.1 in advance, the value of statistical significance of Jarque Bera $0.002557(<0.01)$ then $\mathrm{H} 0$ is rejected, meaning that the regression distribution of ut is not normal.

\section{Heteroscedasticity (White Test)}

Heteroscedasticity test using White Test. H0 White Test there is no problem of heteroscedasticity in the model. HA White Test there is a problem of heteroscedasticity in the model. $\mathrm{H} 0$ is accepted when the statistical significance value $\mathrm{x}^{\wedge} 2>\alpha$ and $\mathrm{H} 0$ is rejected when the significance value $\mathrm{x}^{\wedge} 2<\alpha$. From Table 4.1 in advance the value of $\operatorname{sig}\left(\mathrm{x}^{\wedge} 2\right)=0.1702(>0.10)$ then $\mathrm{H} 0$ is accepted, meaning there is no heteroscedasticity problem in the model. 


\section{Goodneess-of-fit Test}

Test of Existence model using Test F. H0 Test F: $\beta 1=\beta 2$ $=\beta 3=0$, the model used does not exist and its HA: $\beta 1 \neq \beta 2 \neq$ $\beta 3 \neq 0$; the model used exist, $\mathrm{H} 0$ accepted when the statistical probability $\mathrm{F}>\alpha$. $\mathrm{H} 0$ is rejected if the probability statistic $\mathrm{F}<\alpha$. From Table 4.1 in advance the F-statistic probability value of $0.000000(<0.01)$ then $\mathrm{H} 0$ rejected means the model used exist.

From Table 4.1 in advance, the value of R-squared (R2) of 0.843111 or $84.3111 \%$ means Variable Variable Dependent Profitability of Islamic Commercial Bank can be explained by variation of Independent Capital Adequacy Ratio (CAR), Operational and Operating Income (BOPO), Non Perfoming Fund (NPF) of $84.3111 \%$. While the rest of profitability of Islamic Commercial Bank is explained by variation of other variables which are not included in statistical model equal to $15.6889 \%$.

\section{Validity Test of Independent Variables Influence (T- Test)}

The validity test of influence used in this research is t test. H0 test $\mathrm{t}: \beta \mathrm{i}=0$; independent variable to $\mathrm{i}$ has no significant influence and its HA $\beta \mathrm{i} \neq 0$; independent variables to have a significant influence. $\mathrm{H} 0$ is rejected if statistical significance $\mathrm{ti}<\alpha$ and $\mathrm{H} 0$ is accepted when statistical significance ti $>\alpha$. T test results can be seen in Table 2. 
Table 2

Estimation Resulft of Validity Test of Independent Variables Influence (T-Test)

\begin{tabular}{|c|c|c|c|c|}
\hline Variable & $\mathbf{t}$ & Sig.t & Criteria & Conclusion \\
\hline CAR & 0.207152 & 0.8372 & $>0.01$ & Not significant at $\alpha=0.01$ \\
\hline BOPO & -9.075178 & 0.0000 & $<0.01$ & Significant at $\alpha=0.01$ \\
\hline NPF & 0.430049 & 0.6701 & $>0.01$ & Not significant $\alpha=0.01$ \\
\hline
\end{tabular}

Source : Islamic Banking Statistic (organized data)

\section{Interpretation of Influence of Independent Variables}

From the test of validity of advance influence seen that variable which have significant influence to profitability of Islamic Commercial Bank Operational Cost and Operating Income (BOPO). While the variable Capital Adequacy Ratio (CAR), Non Perfoming Fund (NPF) has no significant effect. The coefficient of variable Operational Cost and Operating Income (BOPO) equal to -0.110703 means that if Operational Cost and Operating Income (BOPO) increase $1 \%$ it will cause profitability down by $0.110703 \%$, with other variable notes considered constant. If Operating Cost and Operating Income (BOPO) decreased by $1 \%$ then profitability will increase by $0.110703 \%$.

\section{Economic Interpretation}

Economic interpretation is intended to interpret the results of the analysis of economic sciences on the overall results of the analysis. To know the influence of each independent variable (CAR, BOPO, NPF) to the dependent variable (Profitability) can be seen from the magnitude of the regression coefficients of each variable. The magnitude of the regression coefficient can be seen in the appendix. Interpretation of each regression coefficient value 
of independent variable and dependent variable can be described as following paragraphs

\section{Capital Adequacy Ratio (CAR) Variable}

Capital Adequacy Ratio (CAR) variable has no significant effect on profitability in Islamic Commercial Bank. Decrease in Capital Adequacy Ratio (CAR) in Islamic banks can decrease the profitability implemented by Islamic Commercial Bank. To maximize the increase of Capital Adequacy Ratio (CAR), the issuer is expected to always maintain the capital adequacy level so that in the end with adequate capital adequacy level, the bank's financial performance will increase. because the greater the ratio of Capital Adequacy Ratio (CAR) of a bank, the higher the profit also means the higher the financial performance of the bank. Other research also indicated that Capital Adequacy Ratio (CAR) has no significant effect on ROA, this means ROA changes from the banks in question are not influenced by changes in the Capital Adequacy Ratio (CAR) ratio.

\section{Cost-To-Income Ratio(BOPO) Variable}

Cost-to-Income ratio (BOPO) to Profitability have significant negative effect to profitability. In other words, the increase in Operational Costs and Operating Income (BOPO) can spur a decline in profitability of ROA in Islamic commercial banks. If the bank in running its operations in an efficient way will reduce the ratio of Operational Costs and Operating Income (BOPO) then the income obtained by the bank will increase and also offset the increased profitability. Other researh that Operational Cost and Operating Income (BOPO) have a negative and significant 
impact on profitability. This is evidenced by the significance of Operational Costs and Operating Income (BOPO) is lower than the required maximal significance requirements.

\section{Non Perfoming Fund Variable (NPF)}

Non Perfoming Fund (NPF) variable has no significant effect on profitability that is ROA of Islamic Commercial Bank. So the greater the Non Perfoming Fund (NPF), will result in a decrease in Return On Assets (ROA), which means the financial performance of banks decreased because of the greater credit risk. Therefore, the Bank in handling the Non Perfoming Fund (NPF) rescheduling, which is to rescheduling the installment period and to minimize the installment amount. Reconditioning also becomes one of the alternative banks in dealing with Non Perfoming Fund (NPF) problem, that is minimize profit margin or profit sharing.

Other previous research showed that the variable Non Perfoming Fund (NPF) has a significant effect on profitability.

\section{CONCLUSION}

From research process this paper demonstrate a number of findings that can be used as a conclusion. These conclusions are the findings of the analysis by the authors. In seeking the influence of Capital Adequacy Ratio (CAR), Cost-to- Income (BOPO), Non Performing Financing (NPF) to profitability of Islamic Commercial Bank. The formulation of the problem thus can be answered clearly. These facts are the answer and the final part of the initial question on the formulation of the problem during the preparation of the study. Based on the research that has been described above statistically, then to obtain a more comprehensive 
description of research results will be reviewed further each data calculation results in accordance with the underlying financial aspects, can be described below:

1. The variable of CapitalAdequancy Ratio (CAR) does not significantly affect the ROA. It is busy with the test $t$ with a significant significance of 0.8372 greater than 0.01 .

2. The variable of Cost-to-Income Ratio (BOPO) is negatively influential to ROA. It is busy with the test $t$ with a significant significance of 0.0000 being significantly less than 0.01 .

3. The Non-performing Financing (NPF) variable does not affect the ROA. It is busy with the test $t$ with a significant significance of 0.6701 more significant than 0.01 .

4. The result of testing of hypothesis shows that $\mathrm{F}$ calculate 55,53079 with significant value of 0.000000 , because it is more significant than 0.01 then Ho is rejected and receives Ha. It may be stated that the significant effect of Capital Investment Equity Ratio (CAR), International Operational Costs and Revenue (BOPO), and Non Performing Financing (NPF) secarasimultant to ROA.

This research provides several suggestions related to the research that already conducted. The management of the Islamic Commercial Banks is expected to pay attention to the variables of CapitalAdequancy Ratio (CAR) and Cost-to-Income (BOPO) ratio. Management of Islamic Commercial Bank should be able to operate the available capital of the operational activities, so that if the bank has a high Capital Investment Equity Ratio (CAR), it increases the profitability of the bank and the unpredictable providers are in good condition to keep the funds held unemployed. In terms of Cost-To-Income (BOPO) ratio is instantly greater 
than (-9.075178). This indicates that the operational activities of banks are inefficient, because management needs to be more costeffective and the costs incurred by the bank to make the profitrate gained by the bank itself.

\section{REFERENCE}

Dendawijaya, L., 2009. Manajemen Perbankan, Jakarta: Ghalia Indonesia.

Iskandar, Aprigati, B. \& Laila, N., 2016. Pengaruh Komponen Risk - Based Bank Rating Terhadap Profitabilitas Bank Umum Syariah di Indonesia ( Periode 2011-2014. Jurnal Ekonomi Syari'ah Teori dan Terapan., 3(3).

Kasmir, 2005. Bank dan Lembaga Keuangan Lainnya, Jakarta: Raja Grafindo.

Muhammad, 2005. Pengantar Akuntansi Syariah, Jakarta: Salemba Empat.

Nadratuzzaman, M., 2013. Produk Keuangan Islam di Indonesia dan Malaysia, Jakarta: Gramedia Pustaka Utama.

Siamat, D., 2007. Manajemen Lembaga Keuangan, Jakarta: Lembaga Penerbit FE UI.

Suhardjono, M.K., 2005. Manajemen Perbankan, Teori dan Aplikasi Cetakan 2.,

Suwiknyo, D., 2010. Kompilasi Tafsir Ayat-Ayat Ekonomi Islam Cetakan 1., Yogyakarta: Pustaka Pelajar.

Wibowo, Satriyo, E. \& Syaichu, M., 2013. Analisis Pengaruh Suku Bunga, Inflasi, CAR, BOPO, NPF Terhadap Profitabilitas Bank Syariah. Journal Of Management, 2(2). 